https://www.journal-imab-bg.org

Original article

\title{
EFFECT OF OLIGOSACCHARIDES ON EN- ZYMES OF CARBOHYDRATE METABOLISM AND ANTIOXIDANT PROTECTION IN IN VITRO TREATED ERYTHROCYTES UNDER CONDI- TIONS OF HYPERGLYCEMIA
}

\author{
Ivica Dimov $^{1}$, Mariya Choneva ${ }^{1}$, Ilia lliev $^{2}$, Anelia Bivolarska ${ }^{1}$ \\ 1)Department of Biochemistry, Faculty of Pharmacy, Medical University of \\ Plovdiv, Bulgaria \\ 2)Department of Biochemistry and Microbiology, Faculty of Biology, Plovdiv \\ University "Paisii Hilendarski”, Bulgaria.
}

\begin{abstract}
Introduction: The purpose of this experiment is to examine the effect of different oligosaccharides with proven prebiotic effects on enzymes of carbohydrate metabolism and the antioxidant protection of erythrocytes in vitro under conditions of hyperglycemia.

Materials and methods: This experiment included 10 healthy men $(27 \pm 3$ years of age). The isolated erythrocytes were treated with $1 \%$ and $5 \%$ solutions of the following oligosaccharides: lactulose, inulin, galactooligosaccharide and fructooligosaccharide in the presence of $5 \mathrm{mM}, 50 \mathrm{mM}$ and $100 \mathrm{mM}$ glucose. After incubation, for 2 hours at $37^{\circ} \mathrm{C}$, the erythrocytes were lysed, and the supernatant was used for analyses of lactate dehydrogenase, hexokinase and glutathione reductase. FRAP (Ferric reducing antioxidant power) method was used for determining the total antioxidant activity of erythrocytes.

Results: Lactate dehydrogenase was decreased in the presence of $5 \%$ lactulose in groups with $50 \mathrm{mM}$ and $100 \mathrm{mM}$ Glc. An increase in the activity of glutathione reductase under severe hyperglycemia $(100 \mathrm{mM}$ glucose) was observed after treatment with: $1 \%$ lactulose, $1 \%$ inulin, $1 \%$ galactooligosaccharide, $1 \%$ and $5 \%$ fructooligosaccharides $(\mathrm{p}<0.005)$. A significant difference in the enzymatic activity of hexokinase was found in all groups $(\mathrm{p}<0.05)$ and of glutathione reductase only in the control group as well as in the groups treated with $1 \%$ lactulose, $1 \%$ galactooligosaccharide, $1 \%$ and $5 \%$ fructooligosaccharides.

Conclusions: Galactooligosaccharides $1 \%$ and fructooligosaccharides $1 \%$ and $5 \%$ cause a statistically significant increase of the enzymatic activities of hexokinase and glutathione reductase in in vitro hyperglycemia induced by $100 \mathrm{mM}$ glucose, as well as an increase in FRAP.
\end{abstract}

Keywords: prebiotics, oligosaccharides, hyperglycemia, erythrocytes, antioxidant protection,

\section{INTRODUCTION}

Prebiotics are indigestible nutrients, which selectively stimulate the growth, composition and activity of the intestinal microflora and therefore improve the health and the wellbeing of the host. They are not affected by the severe conditions in the gastrointestinal tract and cause more changes to the microflora compared to probiotics $[1$, 2].

In the metabolism of prebiotics by the beneficial microflora, the increased concentration of short-chain fatty acids (SCFAs) (acetate, propionate, butyrate) is well established $[3,4]$. They bind specific cell receptors - G-protein coupled receptors (GPCR41 and GPCR43), which boost the normal functioning of the intestinal mucosa and stimulate the immune system by inhibiting the production of interleukin (IL) -6 , IL-1 $\beta$, tumor necrosis factor- $\alpha$ and nitric oxide, but they increase the production of anti-inflammatory cytokine IL-10 by stimulating the GPCRs inhibiting the histone deacetylase (HDAC) [5]. Prebiotics can improve glucose homeostasis through two separate mechanisms: (1) regulation of the glucagon like peptide 1 (GLP1 ) for improving the function of the $\beta$-cells and (2) decreasing the permeability of the intestinal wall for bacterial lipopolysaccharides (LPS) from gram-negative microorganisms, which could lead to an improvement of the insulin sensitivity [6].

Prebiotics are mainly of carbohydrate origin and refer to the following oligosaccharides: fructans (inulin and fructooligosaccharides - FOS) [7, 8], galactans (galactooligosaccharides - GOS) [8, 9], lactulose [10], xylooligosaccharides (XOS) $[11,8,12]$, manooligosaccharides (MOS) [13], oligosaccharides from human milk (HMO) [8].

Diabetes mellitus (DM) represents a group of metabolic violations characterized by the presence of hyperglycemia in the absence of treatment. The heterogeneous etiopathology includes defects in the secretion of insulin, in insulin's action or in both, as well as disorders of the metabolism of carbohydrates, lipids and proteins. In 2014 there were 422 million people registered with diabetes worldwide, and their count is expected to grow to 629 million by 2045 if the disease is not limited [14]. According 
to the International Diabetes Federation (IDF), in 2019, there were approximately 463 million adults with diabetes, which proves the tendency of the cases to rise.

One of the main factors for the progression of diabetes complications is hyperglycemia. It is associated with complications on molecular, cellular and organ level, which lead to cardiovascular diseases, neuropathies, nephropathies, blindness, limb amputations, etc. Although erythrocytes are energetically dependent on glucose, hyperglycemia leads to a decrease in the number of $\mathrm{Na}^{+} / \mathrm{K}^{+}$-ATPases and $\mathrm{Ca}^{2+}$-ATPases in their membranes, glycation of proteins (hemoglobin and enzymes), lipid peroxidation, a decrease of their mobility, shortening of their half-life, etc. $[15,16]$. Glucose enters erythrocytes through non-insulin dependent transporter GLUT1. Because of the lack of mitochondria, the metabolism of glucose, which follows the EmbdenMeyerhof pathway, leads to the formation of lactate or pyruvate and the generation of adenosine triphosphate (ATP), required for various metabolic processes as well as for the maintenance of the shape of erythrocytes. 3-11\% of the glucose used by erythrocytes undergoes the pentose phosphate pathway in physiologic conditions. This pathway plays a significant role in the maintenance of the oxidizable components of erythrocytes in a reduced state by providing a redox potential in the form of reduced nicotinamide adenine dinucleotide phosphate (NADPH) [17]. Glycolysis is strictly regulated by three irreversible reactions catalyzed by: hexokinase (HK; EC 2.7.1.1), phosphofructokinase (PFK; EC 2.7.1.11) and pyruvate kinase (PK; EC 2.7.1.40). It has also been reported that the intracellular concentrations of the intermediate metabolites of glycolysis significantly change in erythrocytes of patients with diabetes and also that there is lactic acidosis due to the increased activity of lactate dehydrogenase (LDH) [18]. HK has four isoforms and the first isoform of HK (HK I) is expressed mainly in tissues and erythrocytes [19]. Erythrocytes are constantly under oxidative stress because of the elevated oxygen level, the presence of hemoglobin, fatty acids in the membranes, etc. Oxidative processes can lead to a number of disorders of erythrocyte metabolism as well as a full loss of function. Erythrocytes have several physiological defense mechanisms against intracellular oxidative stress, and these are the antioxidant enzymes: superoxide dismutase (SOD), catalase (CAT), glutathione $\mathrm{S}$-transferase (GST) and glutathione reductase (GR). GR is important for the maintenance of the levels of reduced glutathione [20].

The purpose of the present experiment is to examine the effect of different oligosaccharides with proven prebiotic effect on enzymes of carbohydrate metabolism and the antioxidant protection of erythrocytes in vitro under conditions of hyperglycemia.

\section{MATERIALS AND METHODS}

\section{Ethical approval}

This experiment was conducted in accordance with the ethical principles of The Declaration of Helsinki on $\mathrm{Hu}-$ man Experiments. All procedures were approved by the ethical commission (protocol No.2/13.06.2019) of the Medical University of Plovdiv. Written informed approval was obtained by all participants before the study.

\section{Reagents and equipment}

Reagents provided by Chema Diagnostic (Monsano An, Italy) were used for the determination of lactate dehydrogenase (LDH) activity. The hexokinase (HK) and the glutathione reductase (GR) were determined with reagents provided by Sigma Aldrich, US. The spectrophotometric measurements were performed on an 800 DU spectrophotometer (Beckman Coulter ${ }^{\circ}$, Brea, CA, the U.S.).

\section{Isolation, treatment and lysis of erythrocytes}

The donors included in this experiment were 10 young men, $27 \pm 3$ years of age, clinically healthy, with no chronic diseases, who do not administer any drugs. Each sample was processed and analysed separately. Erythrocytes were isolated from blood, taken by venipuncture in vacuum containers containing EDTA as an anticoagulant. Initially, the blood was centrifuged at $3000 \mathrm{rpm}$ for 20 minutes at $4{ }^{\circ} \mathrm{C}$. The plasma and the lymphocytes were separated by aspiration, and the remaining cells were washed by adding 4 volumes of PBS buffer, $\mathrm{pH}$ 7.4. Then they were centrifuged at $3000 \mathrm{rpm}$ for 10 minutes at $4^{\circ} \mathrm{C}$. The process was repeated twice more (three washings all together). The erythrocytes were treated with $1 \%$ and $5 \%$ solutions of the following oligosaccharides (diluted in PBS buffer, $\mathrm{pH}$ 7.4): lactulose, inulin, galactooligosaccharide (GOS) and fructooligosaccharide (FOS) in the presence of $5 \mathrm{mM}, 50 \mathrm{mM}$ and $100 \mathrm{mM}$ glucose (Glc), which caused hyperglycemia. The chosen concentrations of glucose have been applied in several studies, which aimed to explain the effect of high glucose concentration on erythrocyte metabolism in in vitro conditions $[15,28,29]$. The samples with the presence of $5 \mathrm{mM}$ glucose represented a control group and simulated the normal physiological conditions in erythrocytes.

After that, the samples were placed in an incubator with a shaker for 2 hours at $37^{\circ} \mathrm{C}$. The treated erythrocytes were centrifuged for 10 minutes at $3000 \mathrm{rpm}$. The supernatant was removed, and the erythrocytes were then washed with PBS buffer.

The erythrocytes were lysed by adding ice-cold water in proportion 1:20 [21]. They were centrifuged for $10 \mathrm{~min}-$ utes at $7000 \mathrm{rpm}$. The separated supernatant was used for the measurement of the relevant enzymatic activities.

\section{Enzyme analyzes}

Lactate dehydrogenase (LDH) is an enzyme, catalyzing a reversible reaction, which reduces pyruvate to lactate in the presence of NADH, which is converted to $\mathrm{NAD}^{+}$ [22]. The rate of the conversion of NADH to $\mathrm{NAD}^{+}$measured at $340 \mathrm{~nm}$ is proportional to $\mathrm{LDH}$ activity. Reagents provided by Chema Diagnostic (Monsano An, Italy) were used for the determination of LDH activity. One $\mathrm{ml}$ of reagent 1 was mixed with $10 \mu \mathrm{l}$ of erythrocytes hemolysate, the mixture was incubated for $5 \mathrm{~min}$ at $37^{\circ} \mathrm{C}$ and after that 250 $\mu \mathrm{l}$ of reagent 2 were added. A measurement of the absorbance at $\lambda=340 \mathrm{~nm}$ against a control, which contained distilled water instead of the hemolysate was performed. Other 5 readings at a 60 seconds interval were performed. Calculated $\Delta \mathrm{A} / \mathrm{min}$ was multiplied by the factor 20080 and $\mathrm{U} / \mathrm{ml}$ was obtained. The specific enzyme activity was determined by the formula: $\mathrm{U} / \mathrm{mg}=(\mathrm{U} / \mathrm{ml}) /(\mathrm{mg} / \mathrm{ml}$ protein $)$.

The method of Bergmeyer and Walter was used for 
the determination of hexokinase (HK) activity [23]. It is based on the measurement of the absorption of NADPH, accumulated in the solution due to the glucose-6-phosphate dehydrogenase reaction, at $340 \mathrm{~nm}$. The reaction mixture contained: $1 \mathrm{ml}$ Tris Buffer (Tris- $\mathrm{HCl}$ ) pH 7.6, $1 \mathrm{ml} 555 \mathrm{mM}$ glucose, $100 \mu \mathrm{l} 19 \mathrm{mM}$ ATP, $200 \mu \mathrm{l} 100 \mathrm{mM} \mathrm{MgCl}, 200 \mu \mathrm{l}$ $14 \mathrm{mM}$ NADP, $20 \mu \mathrm{l} 125 \mathrm{U} / \mathrm{ml}$ glucose-6-phosphate dehydrogenase (Sigma-Aldrich, cat. No. G8404) and $50 \mu \mathrm{l}$ erythrocyte hemolysate, respectively $50 \mu \mathrm{l}$ distilled water in the blank. The contents was mixed by inversion and an increase in the absorption at $340 \mathrm{~nm}$ every $30 \mathrm{sec}$ for 5 minutes was monitored. The equation for calculation of the enzyme activity, that was used, is: Units $/ \mathrm{mL}$ enzyme $=(\Delta \mathrm{A} 340 \mathrm{~nm} / \mathrm{min}$ Test - $\Delta$ A340nm/min Blank)(2.57)(df)/ (6.22)(0.05)

\section{Where:}

$2.57=$ Total volume (in milliliters) of assay

df $=$ Dilution factor at $340 \mathrm{~nm}$

$6.22=$ Millimolar extinction coefficient of â-NADPH

$0.05=$ Volume (in milliliter) of enzyme used

The specific enzyme activity was determined by the formula: $\mathrm{U} / \mathrm{mg}=(\mathrm{U} / \mathrm{ml}) /(\mathrm{mg} / \mathrm{ml}$ protein $)$.

In order to study the antioxidant effects of the oligosaccharides, the enzymatic activity of GR was studied [24]. The oxidized glutathione (GSSG) is reduced to two molecules of reduced glutathione (GSH) in the presence of NADPH. The reaction mixture contained: $650 \mu \mathrm{l}$ of distilled water, $1.5 \mathrm{ml}$ of $100 \mathrm{mM}$ potassium phosphate buffer, $\mathrm{pH} 7.6$, with $3.4 \mathrm{mM}$ EDTA, 100 ìl $30 \mathrm{mM}$ GSSG, $350 \mu \mathrm{l} 0.8 \mathrm{mM}$ NADPH, $300 \mu 11.0 \%$ bovine serum albumin and $100 \mu$ lerythrocyte hemolysate. Blank contained $400 \mu \mathrm{l} 1.0 \%$ bovine serum albumin. The contents was mixed by inversion and a decrease in the absorption at $340 \mathrm{~nm}$ every $30 \mathrm{sec}$ for $5 \mathrm{~min}$ utes was monitored. The equation for calculation of the enzyme activity, that was used, is: Units $/ \mathrm{mL}$ enzyme $=(\Delta \mathrm{A} 340$ $\mathrm{nm} / \mathrm{min}$ Test $-\Delta \mathrm{A} 340 \mathrm{~nm} / \mathrm{min}$ Blank $)(3)(\mathrm{df}) /(6.22)(0.1)$

Where:

3 = Total volume (in milliliters) of assay

$\mathrm{df}=$ Dilution factor at $340 \mathrm{~nm}$

$6.22=$ Millimolar extinction coefficient of $\beta-\mathrm{NADPH}$

$0.1=$ Volume (in milliliter) of enzyme used
The specific enzyme activity was determined by the formula: $\mathrm{U} / \mathrm{mg}=(\mathrm{U} / \mathrm{ml}) /(\mathrm{mg} / \mathrm{ml}$ protein $)$.

\section{erythrocytes}

Determination of the total antioxidant activity of

For this purpose, the FRAP (Ferric reducing antioxidant power) method of Benzie and Strain with certain changes was used [25]. FRAP reagent was made immediately before use by mixing $50 \mathrm{ml}$ of acetate buffer $(300 \mathrm{mM}, \mathrm{pH}$ 3.6), $5 \mathrm{ml}$ of the TPTZ stock solution $(10 \mathrm{mM})$ and $5 \mathrm{ml}$ of $\mathrm{FeCl}_{3}(20 \mathrm{mM})$. Then $2.85 \mathrm{ml}$ FRAP reagent was mixed with $0.15 \mathrm{ml}$ of the supernatant, the mixture was incubated for 30 minutes at $37{ }^{\circ} \mathrm{C}$ in the dark, and the absorption was measured at $593 \mathrm{~nm}$. The results were expressed in micromoles Trolox equivalent.

The level of total protein needed to express the specific enzymatic activity of certain enzymes relative to a milligram of protein (U/mg protein) was measured by the method of Bradford [26].

\section{Statistical methods}

The statistical analyzes were made with the statistical program SPSS, version 19.0 (SPSS Inc., Chicago, IL, USA). The descriptive statistics include a median and $95 \%$ confidence interval (CI) because of the non-Gaussian distribution of the results. The Mann-Whitney U-test was used for the comparison of quantitative variables with a nonGaussian distribution between two independent groups. The Kruskal-Wallis test was applied for the comparison of the quantitative variables of more than 2 independent groups.

\section{RESULTS}

A statistically significant difference in the enzymatic activity of LDH $(\mathrm{p}<0.05)$ in the three subgroups with $5 \mathrm{mM}$ glucose, $50 \mathrm{mM}$ glucose and $100 \mathrm{mM}$ glucose $(5 \mathrm{mM}$ Glc, $50 \mathrm{mM}$ Glc, $100 \mathrm{mM} \mathrm{Glc)}$ was detected in samples treated with $5 \%$ lactulose, $1 \%$ inulin, $1 \%$ GOS, $5 \%$ GOS, $1 \%$ FOS and $5 \%$ FOS (Table 1). A significant difference in the enzymatic activity of HK was detected in all groups $(\mathrm{p}<0.05)$ (Table 1$)$ and of GR - in the control group as well as in the groups treated with $1 \%$ lactulose, $1 \%$ GOS, $1 \%$ FOS and 5\% FOS (Table 1).

Table 1. Descriptive statistics of LDH, HK and GR (U/mg protein) of erythrocytes, treated with oligosaccharides in the presence of $5 \mathrm{mM}, 50 \mathrm{mM}$ and $100 \mathrm{mM}$ glucose

\begin{tabular}{|c|c|c|c|c|c|c|c|c|c|c|}
\hline & & \multicolumn{3}{|c|}{ LDH } & \multicolumn{3}{|c|}{ HK } & \multicolumn{3}{|c|}{ GR } \\
\hline Groups & Subgroups & Median & $\begin{array}{c}95 \% \\
\text { CI }\end{array}$ & $\begin{array}{c}\mathbf{p} \\
\text { (Kruskal- } \\
\text { Wallis } \\
\text { Test) }\end{array}$ & Median & $\begin{array}{c}95 \% \\
\text { CI }\end{array}$ & $\begin{array}{c}\mathbf{p} \\
\text { (Kruskal- } \\
\text { Wallis } \\
\text { Test) }\end{array}$ & Median & $\begin{array}{c}95 \% \\
\text { CI }\end{array}$ & $\begin{array}{c}\mathbf{p} \\
\text { (Kruskal- } \\
\text { Wallis } \\
\text { Test) }\end{array}$ \\
\hline \multirow{3}{*}{$\begin{array}{c}\text { Control } \\
(\mathrm{n}=10)\end{array}$} & $\begin{array}{l}5 \mathrm{mM} \\
\text { Glc }\end{array}$ & 0,95 & $\begin{array}{l}0,88- \\
1,16\end{array}$ & \multirow{3}{*}{0.360} & 0.01 & $\begin{array}{l}0.00- \\
0.002\end{array}$ & \multirow{3}{*}{ 0.001* } & 0.16 & $\begin{array}{c}0.15- \\
0.18\end{array}$ & \multirow{3}{*}{ 0.039* } \\
\hline & $\begin{array}{c}50 \mathrm{mM} \\
\text { Glc }\end{array}$ & 0,89 & $\begin{array}{c}0.74- \\
1.04\end{array}$ & & 0.07 & $\begin{array}{l}0.06- \\
0.08\end{array}$ & & 0.14 & $\begin{array}{l}0.12- \\
0.16\end{array}$ & \\
\hline & $\begin{array}{c}100 \mathrm{mM} \\
\text { Glc }\end{array}$ & 1,01 & $\begin{array}{c}0.87- \\
1.14\end{array}$ & & 0.08 & $\begin{array}{l}0.07- \\
0.09\end{array}$ & & 0.18 & $\begin{array}{c}0.15- \\
0.20\end{array}$ & \\
\hline
\end{tabular}




\begin{tabular}{|c|c|c|c|c|c|c|c|c|c|c|}
\hline \multirow{3}{*}{$\begin{array}{c}\text { Lactulose } \\
1 \% \\
(n=10)\end{array}$} & $\begin{array}{c}5 \mathrm{mM} \\
\mathrm{Glc}\end{array}$ & 0,86 & $\begin{array}{c}0.72- \\
1.06\end{array}$ & \multirow{3}{*}{0.747} & 0.04 & $\begin{array}{l}0.01- \\
0.05\end{array}$ & \multirow{3}{*}{$0.022 *$} & 0.14 & $\begin{array}{l}0.11- \\
0.17\end{array}$ & \multirow{3}{*}{$0.000 *$} \\
\hline & $\begin{array}{c}50 \mathrm{mM} \\
\mathrm{Glc}\end{array}$ & 0,81 & $\begin{array}{l}0.68- \\
1.05\end{array}$ & & 0.05 & $\begin{array}{l}0.04- \\
0.07\end{array}$ & & 0.13 & $\begin{array}{l}0.11- \\
0.17\end{array}$ & \\
\hline & $\begin{array}{c}100 \mathrm{mM} \\
\text { Glc }\end{array}$ & 0,85 & $\begin{array}{c}0.63- \\
1.07\end{array}$ & & 0.07 & $\begin{array}{l}0.04- \\
0.12\end{array}$ & & 0.26 & $\begin{array}{l}0.24- \\
0.30\end{array}$ & \\
\hline \multirow{3}{*}{$\begin{array}{c}\text { Lactulose } \\
5 \% \\
(n=10)\end{array}$} & $\begin{array}{c}5 \mathrm{mM} \\
\text { Glc }\end{array}$ & 0,94 & $\begin{array}{c}0.82- \\
1.14\end{array}$ & \multirow{3}{*}{$0.006 *$} & 0.10 & $\begin{array}{l}0.08- \\
0.11\end{array}$ & \multirow{3}{*}{$0.002 *$} & 0.17 & $\begin{array}{l}0.13- \\
0.18\end{array}$ & \multirow{3}{*}{0.253} \\
\hline & $\begin{array}{c}50 \mathrm{mM} \\
\mathrm{Glc}\end{array}$ & 0,7 & $\begin{array}{c}0.66- \\
0.77\end{array}$ & & 0.09 & $\begin{array}{l}0.07- \\
0.10\end{array}$ & & 0.17 & $\begin{array}{l}0.13- \\
0.20\end{array}$ & \\
\hline & $\begin{array}{c}100 \mathrm{mM} \\
\text { Glc }\end{array}$ & 0.67 & $\begin{array}{l}0.57- \\
0.82\end{array}$ & & 0.04 & $\begin{array}{l}0.02- \\
0.06\end{array}$ & & 0.19 & $\begin{array}{l}0.16- \\
0.24\end{array}$ & \\
\hline \multirow{3}{*}{$\begin{array}{c}\text { Inulin } \\
1 \% \\
(n=10)\end{array}$} & $\begin{array}{c}5 \mathrm{mM} \\
\text { Glc }\end{array}$ & 0.85 & $\begin{array}{c}0.65- \\
1.11\end{array}$ & \multirow{3}{*}{ 0.004* } & 0.11 & $\begin{array}{l}0.09- \\
0.12\end{array}$ & \multirow{3}{*}{$0.005 *$} & 0.23 & $\begin{array}{l}0.16- \\
0.27\end{array}$ & \multirow{3}{*}{0.426} \\
\hline & $\begin{array}{c}50 \mathrm{mM} \\
\mathrm{Glc}\end{array}$ & 0.50 & $\begin{array}{c}0.44- \\
0.60\end{array}$ & & 0.05 & $\begin{array}{c}0.04- \\
0.07\end{array}$ & & 0.20 & $\begin{array}{l}0.16- \\
0.22\end{array}$ & \\
\hline & $\begin{array}{c}100 \mathrm{mM} \\
\text { Glc }\end{array}$ & 0.98 & $\begin{array}{c}0.88- \\
1.06\end{array}$ & & 0.06 & $\begin{array}{l}0.02- \\
0.09\end{array}$ & & 0.20 & $\begin{array}{l}0.18- \\
0.24\end{array}$ & \\
\hline \multirow{3}{*}{$\begin{array}{c}\text { Inulin } \\
\mathbf{5 \%} \\
(\mathbf{n}=\mathbf{1 0})\end{array}$} & $\begin{array}{c}5 \mathrm{mM} \\
\text { Glc }\end{array}$ & 0.98 & $\begin{array}{c}0.73- \\
1.11\end{array}$ & \multirow{3}{*}{0.52} & 0.07 & $\begin{array}{l}0.05- \\
0.08\end{array}$ & \multirow{3}{*}{$0.045 *$} & 0.18 & $\begin{array}{l}0.14- \\
0.23\end{array}$ & \multirow{3}{*}{0.244} \\
\hline & $\begin{array}{c}50 \mathrm{mM} \\
\text { Glc }\end{array}$ & 0.97 & $\begin{array}{c}0.86- \\
1.12\end{array}$ & & 0.09 & $\begin{array}{c}0.07- \\
0.12\end{array}$ & & 0.14 & $\begin{array}{c}0.11- \\
0.17\end{array}$ & \\
\hline & $\begin{array}{c}100 \mathrm{mM} \\
\text { Glc }\end{array}$ & 0.81 & $\begin{array}{l}0.70- \\
0.91\end{array}$ & & 0.07 & $\begin{array}{l}0.04- \\
0.10\end{array}$ & & 0.11 & $\begin{array}{l}0.09- \\
0.21\end{array}$ & \\
\hline \multirow{3}{*}{$\begin{array}{c}\text { GOS } \\
1 \% \\
(n=10)\end{array}$} & $\begin{array}{c}5 \mathrm{mM} \\
\mathrm{Glc}\end{array}$ & 1,11 & $\begin{array}{l}1.04- \\
1.20\end{array}$ & \multirow{3}{*}{$0.001 *$} & 0.05 & $\begin{array}{l}0.04- \\
0.05\end{array}$ & \multirow{3}{*}{$0.004 *$} & 0.14 & $\begin{array}{l}0.11- \\
0.17\end{array}$ & \multirow{3}{*}{$0.000 *$} \\
\hline & $\begin{array}{c}50 \mathrm{mM} \\
\text { Glc }\end{array}$ & 0.71 & $\begin{array}{l}0.59- \\
0.84\end{array}$ & & 0.16 & $\begin{array}{c}0.11- \\
0.19\end{array}$ & & 0.18 & $\begin{array}{l}0.12- \\
0.20\end{array}$ & \\
\hline & $\begin{array}{c}100 \mathrm{mM} \\
\text { Glc }\end{array}$ & 1,23 & $\begin{array}{l}1.17- \\
1.31\end{array}$ & & 0.09 & $\begin{array}{l}0.04- \\
0.15\end{array}$ & & 0.28 & $\begin{array}{l}0.25- \\
0.32\end{array}$ & \\
\hline \multirow{3}{*}{$\begin{array}{c}\text { GOS } \\
\mathbf{5 \%} \\
(n=10)\end{array}$} & $\begin{array}{c}5 \mathrm{mM} \\
\mathrm{Glc}\end{array}$ & 0.82 & $\begin{array}{c}0.74- \\
0.89\end{array}$ & \multirow{3}{*}{$0.002 *$} & 0.09 & $\begin{array}{l}0.07- \\
0.10\end{array}$ & \multirow{3}{*}{$0.008 *$} & 0.15 & $\begin{array}{l}0.13- \\
0.18\end{array}$ & \multirow{3}{*}{0.992} \\
\hline & $\begin{array}{c}50 \mathrm{mM} \\
\text { Glc }\end{array}$ & 1,04 & $\begin{array}{c}0.50- \\
1.29\end{array}$ & & 0.13 & $\begin{array}{l}0.12- \\
0.16\end{array}$ & & 0.14 & $\begin{array}{l}0.12- \\
0.20\end{array}$ & \\
\hline & $\begin{array}{c}100 \mathrm{mM} \\
\text { Glc }\end{array}$ & 1,21 & $\begin{array}{l}1.13- \\
1.30\end{array}$ & & 0.09 & $\begin{array}{l}0.07- \\
0.12\end{array}$ & & 0.14 & $\begin{array}{l}0.11- \\
0.23\end{array}$ & \\
\hline \multirow{3}{*}{$\begin{array}{c}\text { FOS } \\
1 \% \\
(n=10)\end{array}$} & $\begin{array}{c}5 \mathrm{mM} \\
\mathrm{Glc}\end{array}$ & 0.86 & $\begin{array}{l}0.80- \\
0.94\end{array}$ & \multirow{3}{*}{$0.001 *$} & 0.07 & $\begin{array}{l}0.05- \\
0.07\end{array}$ & \multirow{3}{*}{$0.002 *$} & 0.17 & $\begin{array}{l}0.11- \\
0.18\end{array}$ & \multirow{3}{*}{$0.000 *$} \\
\hline & $\begin{array}{c}50 \mathrm{mM} \\
\text { Glc }\end{array}$ & 1,09 & $\begin{array}{c}1.04- \\
1.14\end{array}$ & & 0.12 & $\begin{array}{c}0.10- \\
0.12\end{array}$ & & 0.22 & $\begin{array}{l}0.15- \\
0.25\end{array}$ & \\
\hline & $\begin{array}{c}100 \mathrm{mM} \\
\text { Glc }\end{array}$ & 1,27 & $\begin{array}{l}1.20- \\
1.38\end{array}$ & & 0.11 & $\begin{array}{l}0.10- \\
0.11\end{array}$ & & 0.30 & $\begin{array}{l}0.25- \\
0.34\end{array}$ & \\
\hline \multirow{3}{*}{$\begin{array}{c}\text { FOS } \\
5 \% \\
(n=10)\end{array}$} & $\begin{array}{c}5 \mathrm{mM} \\
\text { Glc }\end{array}$ & 1,29 & $\begin{array}{l}1.18- \\
1.54\end{array}$ & \multirow{3}{*}{$0.001 *$} & 0.07 & $\begin{array}{c}0.06- \\
0.09\end{array}$ & \multirow{3}{*}{ 0.019* } & 0.17 & $\begin{array}{l}0.12- \\
0.19\end{array}$ & \multirow{3}{*}{$0.002 *$} \\
\hline & $\begin{array}{c}50 \mathrm{mM} \\
\text { Glc }\end{array}$ & 0.80 & $\begin{array}{c}0.69- \\
0.89\end{array}$ & & 0.09 & $\begin{array}{l}0.07- \\
0.11\end{array}$ & & 0.15 & $\begin{array}{l}0.11- \\
0.20\end{array}$ & \\
\hline & $\begin{array}{c}100 \mathrm{mM} \\
\text { Glc }\end{array}$ & 1,02 & $\begin{array}{c}0.93- \\
1.08\end{array}$ & & 0.11 & $\begin{array}{c}0.09- \\
0.13\end{array}$ & & 0.25 & $\begin{array}{c}0.21- \\
0.30\end{array}$ & \\
\hline
\end{tabular}

*statistical significant 
When comparing the enzymatic activity of LDH (Table 3) of groups treated with different oligosaccharides with the control group (LDH values above the median of the control $0.95 \mathrm{U} / \mathrm{mg}$ protein - Table 1), in the groups with the presence of $5 \mathrm{mM}$ glucose, a statistically significant increase was found only in the groups, treated with $5 \%$ FOS $(\mathrm{p}=0.004)$. No statistically significant increase was found in the groups with $50 \mathrm{mM} \mathrm{Glc}(\mathrm{p}>0.05)$. Only three of the groups with the presence of $100 \mathrm{mM} \mathrm{Glc}$, showed a statistically significant increase: the groups with $1 \%$ GOS ( $\mathrm{p}=$ $0.012), 5 \%$ GOS $(p=0.036)$ and $1 \%$ FOS $(p=0.006)$.

When comparing the enzymatic activity of HK (Table 3) of groups treated with different oligosaccharides with the control group (HK values above the median of the control $0.01 \mathrm{U} / \mathrm{mg}$ protein - Table 1 ), it was proven that all groups show a statistically significant difference $(\mathrm{p}<0.05)$, with the exception of the group with $5 \mathrm{mM}$ Glc, when treated with $1 \%$ lactulose.

When comparing the enzymatic activity of GR (Ta- ble 3) of groups treated with different oligosaccharides with the control group (GR values above the median of the control $0.16 \mathrm{U} / \mathrm{mg}$ protein - Table 1 ), a statistically significant difference was found only in the group with $5 \mathrm{mM}$ Glc, when treated with $1 \%$ inulin $(\mathrm{p}=0.037)$. In the rest of the groups, a statistically significant difference was not found ( $p>0.05)$.

In the groups with $50 \mathrm{mM}$ Glc, a statistically significant difference was not found anythem. Unlike these groups, in the groups with $100 \mathrm{mM}$ Glc a statistically significant difference in the enzyme activity of GR was found in the groups, treated with $1 \%$ lactulose $(\mathrm{p}=0.000), 1 \%$ inulin $(\mathrm{p}=0.018), 1 \%$ GOS $(\mathrm{p}=0.000), 1 \%$ FOS $(\mathrm{p}=0.000)$ and $5 \%$ FOS $(\mathrm{p}=0.0001)$. In the rest of the groups' such difference was missing $(\mathrm{p}>0.05)$.

From Table 2, it can be seen that a statistically significant difference regarding FRAP in the three subgroups was found in control, as well as in the groups treated with $1 \%$ lactulose, $1 \%$ inulin, $5 \%$ inulin, $1 \%$ GOS, $1 \%$ FOS and $5 \%$ FOS.

Table 2. Descriptive statistics of FRAP ( $\mu$ mol Trolox equivalent) of erythrocytes, treated with oligosaccharides in the presence of $5 \mathrm{mM}, 50 \mathrm{mM}$ and $100 \mathrm{mM}$ glucose

\begin{tabular}{|c|c|c|c|c|}
\hline & & \multicolumn{3}{|c|}{ FRAP } \\
\hline Groups & Subgroups & Median & $95 \% \mathrm{CI}$ & $\underset{\text { (Kruskal- Wallis Test) }}{\text { P }}$ \\
\hline \multirow{3}{*}{$\begin{array}{l}\text { Control } \\
(n=10)\end{array}$} & $5 \mathrm{mM}$ Glc & 0.99 & $0.95-1.02$ & \multirow{3}{*}{$0.005 *$} \\
\hline & $50 \mathrm{mM} \mathrm{Glc}$ & 1,08 & $1.02-1.13$ & \\
\hline & $100 \mathrm{mM} \mathrm{Glc}$ & 1,07 & $1.02-1.11$ & \\
\hline \multirow{3}{*}{$\begin{array}{l}\text { Lactulose } 1 \% \\
\qquad(n=10)\end{array}$} & $5 \mathrm{mM}$ Glc & 0.87 & $0.85-0.89$ & \multirow[t]{3}{*}{$0.000 *$} \\
\hline & $50 \mathrm{mM}$ Glc & 1,09 & $1.08-1.11$ & \\
\hline & 100mM Glc & 0.98 & $0.97-0.99$ & \\
\hline \multirow{3}{*}{$\begin{array}{c}\text { Lactulose } 5 \% \\
\qquad(n=10)\end{array}$} & $5 \mathrm{mM}$ Glc & 0.77 & $0.73-0.87$ & \multirow{3}{*}{0.196} \\
\hline & $50 \mathrm{mM} \mathrm{Glc}$ & 0.86 & $0.81-0.90$ & \\
\hline & $100 \mathrm{mM} \mathrm{Glc}$ & 0.82 & $0.76-0.86$ & \\
\hline \multirow{3}{*}{$\begin{array}{c}\text { Inulin 1\% } \\
(\mathrm{n}=10)\end{array}$} & $5 \mathrm{mM}$ Glc & 0.75 & $0.73-0.84$ & \multirow{3}{*}{$0.000 *$} \\
\hline & $50 \mathrm{mM}$ Glc & 1,05 & 01.1 .2011 & \\
\hline & $100 \mathrm{mM} \mathrm{Glc}$ & 1,07 & $1.05-1.08$ & \\
\hline \multirow{3}{*}{$\begin{array}{c}\text { Inulin 5\% } \\
(n=10)\end{array}$} & $5 \mathrm{mM}$ Glc & 0.81 & $0.77-0.87$ & \multirow{3}{*}{$0.000 *$} \\
\hline & $50 \mathrm{mM}$ Glc & 1,04 & $0.97-1.10$ & \\
\hline & 100mM Glc & 1,12 & $1.11-1.12$ & \\
\hline \multirow{3}{*}{$\begin{array}{c}\text { GOS } 1 \% \\
(n=10)\end{array}$} & 5mM Glc & 1,04 & $0.95-1.10$ & \multirow{3}{*}{$0.000 *$} \\
\hline & $50 \mathrm{mM} \mathrm{Glc}$ & 1,07 & $1.03-1.09$ & \\
\hline & $100 \mathrm{mM} \mathrm{Glc}$ & 1,15 & $1.12-1.21$ & \\
\hline \multirow{3}{*}{$\begin{array}{c}\text { GOS 5\% } \\
(n=10)\end{array}$} & $5 \mathrm{mM}$ Glc & 1,11 & $0.94-1.30$ & \multirow{3}{*}{0.608} \\
\hline & 50mM Glc & 1,15 & $1.12-1.18$ & \\
\hline & 100mM Glc & 1,17 & $1.15-1.22$ & \\
\hline \multirow{3}{*}{$\begin{array}{c}\text { FOS 1\% } \\
(n=10)\end{array}$} & 5mM Glc & 1 & $0.96-1.06$ & \multirow{3}{*}{$0.000 *$} \\
\hline & $50 \mathrm{mM}$ Glc & 1,14 & $1.13-1.15$ & \\
\hline & $100 \mathrm{mM} \mathrm{Glc}$ & 1,17 & $1.14-1.20$ & \\
\hline \multirow{3}{*}{$\begin{array}{c}\text { FOS 5\% } \\
(\mathrm{n}=10)\end{array}$} & $5 \mathrm{mM}$ Glc & 1,13 & $1.02-1.18$ & \multirow{3}{*}{$0.027 *$} \\
\hline & 50mM Glc & 1,07 & $1.04-1.09$ & \\
\hline & $100 \mathrm{mM} \mathrm{Glc}$ & 1,12 & $1.10-1.13$ & \\
\hline
\end{tabular}

*statistical significant 
When comparing FRAP (Table 3) of groups treated with different oligosaccharides with the control group (FRAP values above the median of the control $0.99 \mu \mathrm{mol}$ Trolox equivalent - Table 2), a statistically significant increase was found in the groups with the presence of $5 \mathrm{mM}$ Glc, treated with 5\% FOS $(\mathrm{p}=0.015)$. In the groups with the presence of $50 \mathrm{mM}$ Glc, a statistically significant in- crease was found in the groups treated with $1 \%$ lactulose, $1 \%$ inulin, $1 \%$ GOS, $5 \%$ GOS, $1 \%$ FOS and $5 \%$ FOS $(\mathrm{p}<0.05)$. In the groups with the most severe hyperglycemia in the presence of $100 \mathrm{mM}$ Glc, a statistically significant increase $(\mathrm{p}<0.05)$ was found in all groups except for the ones treated with $1 \%$ and $5 \%$ lactulose.

Table 3. Comparative characteristics between the control group (erythrocytes, treated with $5 \mathrm{mM}$ glucose) and all other groups, examined with Mann-Whitney U test

\begin{tabular}{|c|c|c|c|c|c|}
\hline & & $\begin{array}{c}\text { LDH } \\
\text { (p) }\end{array}$ & $\begin{array}{c}\text { Hexokinase } \\
\text { (p) }\end{array}$ & $\begin{array}{l}\text { GR } \\
(\mathbf{p})\end{array}$ & $\begin{array}{c}\text { FRAP } \\
\text { (p) }\end{array}$ \\
\hline \multirow{8}{*}{$\sum_{\text {है }}^{\stackrel{\circlearrowright}{V}}$} & Lactulose $1 \%$ & 0.107 & 0.074 & 0.148 & $0.000 * *$ \\
\hline & Lactulose 5\% & 0.467 & 0.004* & 0.568 & $0.000 * *$ \\
\hline & Inulin $1 \%$ & 0.222 & 0.004* & $0.037 *$ & $0.000 * *$ \\
\hline & Inulin 5\% & 0.747 & 0.004* & 0.469 & $0.000^{* *}$ \\
\hline & GOS $1 \%$ & 0.146 & 0.006* & 0.111 & 0.699 \\
\hline & GOS 5\% & $0.005^{* *}$ & 0.004* & 0.209 & 0.785 \\
\hline & FOS $1 \%$ & $0.024 * *$ & 0.004* & 0.237 & 0.716 \\
\hline & FOS 5\% & 0.004* & 0.004* & 0.909 & 0.015* \\
\hline \multirow{8}{*}{ 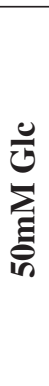 } & Lactulose $1 \%$ & 0.107 & 0.004* & 0.052 & 0.000* \\
\hline & Lactulose 5\% & $0.004 * *$ & 0.004* & 0.620 & 0.000 \\
\hline & Inulin $1 \%$ & $0.004 * *$ & 0.005* & 0.068 & 0.012* \\
\hline & Inulin 5\% & 0.807 & 0.004* & 0.087 & 0.163 \\
\hline & GOS $1 \%$ & $0.004 * *$ & 0.004* & 0.675 & $0.000 *$ \\
\hline & GOS 5\% & 0.747 & 0.004* & 0.404 & 0.000* \\
\hline & FOS $1 \%$ & 0.332 & 0.003* & 0.197 & 0.000* \\
\hline & FOS 5\% & $0.006 * *$ & 0.004* & 0.223 & 0.000* \\
\hline \multirow{8}{*}{ 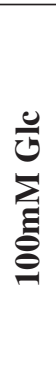 } & Lactulose $1 \%$ & 0.333 & 0.004* & $0.000 *$ & 0.536 \\
\hline & Lactulose 5\% & $0.004 * *$ & 0.015* & 0.223 & $0.000 * *$ \\
\hline & Inulin $1 \%$ & 0.872 & 0.013* & 0.018* & 0.000* \\
\hline & Inulin 5\% & $0.012^{* *}$ & $\mathrm{0.005}^{*}$ & 0.130 & 0.000* \\
\hline & GOS $1 \%$ & 0.012* & 0.035* & 0.000* & 0.000* \\
\hline & GOS 5\% & $0.036 *$ & 0.004* & 0.383 & 0.000* \\
\hline & FOS $1 \%$ & 0.006* & 0.004* & 0.000* & $0.000 *$ \\
\hline & FOS 5\% & 0.747 & 0.004* & 0.001* & 0.000* \\
\hline
\end{tabular}

* statistically significant increase of the respective indicator relative to control- erythrocytes, treated with $5 \mathrm{mM}$ Glc ** statistically significant decrease of the respective indicator relative to control- erythrocytes, treated with $5 \mathrm{mM}$ Glc

\section{DISCUSSION}

Hyperglycemia causes various changes in structure, functions and longevity of erythrocytes. These changes could be due to oxidative stress, which leads to an increase in lipid peroxidation. This peroxidation and the accumulation of malondialdehyde can lead to a disruption of the organization of the phospholipid bilayer and hence the inability of glucose intake from erythrocytes [27]. From table 1 and table 3, it can be seen that under the condition of hyperglycemia in the presence of all oligosaccharides, there is an increase in the activity of the initial enzyme, which activates glucose in erythrocytes, precisely HK. High concentration of glucose can cause posttranslational modification in the structure of proteins which serve as an enzymes and that is why some grups showed a decrease in the enzyme activity of HK after treatment with $100 \mathrm{mM}$ of glucose comparing with those treated with $50 \mathrm{mM}$ of glucose. It can be assumed that there is no competition between the various oligosaccharides and glucose for GLUT1, and it enters erythrocytes unimpeded. We cannot say if or how oligosaccharides additionally activate HK, but we can say that in the condition of hyperglycemia, there is not inhibition of HK.

It is known that the erythrocytes of patients with diabetes have structural and functional changes. Altered concentrations of glycolytic chain metabolites, as well as accumulation of lactate due to increased activity of $\mathrm{LDH}$, are also observed [18]. Our results confirm the literature data, as a statistically significant increase in the activity of LDH was found under the condition of hyperglycemia, caused by the presence of $100 \mathrm{mM} \mathrm{Glc}$, in erythrocytes, treated with $1 \%$ $\operatorname{GOS}(\mathrm{p}=0.012), 5 \%$ GOS ( $\mathrm{p}=0.036)$ and 1\% FOS ( $\mathrm{p}=0.006)$. It is an interesting fact that in some of the groups, a statisti- 
cally significant decrease in the activity of LDH was observed relative to the median of the control. In the condition of hyperglycemia, caused by $50 \mathrm{mM} \mathrm{Glc}$, a decrease of LDH was observed in the following groups: $5 \%$ lactulose $(\mathrm{p}=0.004), 1 \%$ inulin $(\mathrm{p}=0.004), 1 \%$ GOS $(\mathrm{p}=0.004)$ and $5 \%$ FOS $(p=0.006)$. In the groups with the presence of $100 \mathrm{mM}$ Glc, a statistically significant decrease of LDH was observed in the following groups: $5 \%$ lactulose $(\mathrm{p}=0.004)$ and $5 \%$ inulin $(p=0.012)$ (Table 3). Our explanation is that the decrease of $\mathrm{LDH}$ in these groups may be due to the redirection of metabolites towards the pentose phosphate pathway because of the increased oxidative stress under the conditions of hyperglycemia and the activation of antioxidant enzymes which protect erythrocytes. This is partially supported by our results on the activities of enzymes involved in the antioxidant protection of these cells.

Glutathione is an important intracellular antioxidant, which is maintained in a reduced state through the pentose phosphate pathway, which uses $3-11 \%$ of the glucose in erythrocytes. This is the only pathway, which generates NADPH needed for the decrease of the oxidized glutathione (GSSG) [15] via the action of GR [20]. In literature, there are contradictory data regarding the activity of GR in conditions of hyperglycemia. Viskupicova et al. have established that under in vitro conditions of hyperglycemia, there is a decrease in the activities of GR and GST [15]. We obtained a statistically significant increase in the activity of GR under the condition of severe hyperglycemia (100mM Glc) after treatment with the following oligosaccharides: $1 \%$ lactulose, $1 \%$ inulin, $1 \%$ GOS, $1 \%$ FOS and $5 \%$ FOS $(\mathrm{p}<0.005)$ (Table 3$)$. This can be due to the eventual influence of these oligosaccharides on the membrane protein systems Syk, Lyn and band 3 . These systems bind some of the enzymes of erythrocytes and distribute the use of glucose in a balanced way, both in glycolysis and in the pentose phosphate pathway. Under the conditions of hyperglycemia, oligosaccharides decrease the rate of glycolysis and activate the production of NADPH in the pentose phosphate pathway and, in this way, enhance the protective mechanisms of the erythrocyte [16].

Because of the increased production of reactive oxygen species under conditions of hyperglycemia, the total antioxidant capacity of erythrocytes increases in the presence of various oligosaccharides, which can be seen from the data about FRAP (Table 3). A correlation between GR and FRAP was not established, which may be due to the activation of some other antioxidant enzymes by oligosaccharides, which actually lead to an increase in total antioxidant capacity.

\section{CONCLUSION}

Due to the lack of data in the literature on in vitro experiments on erythrocytes treated with oligosaccharides, we offer a new perspective on changes in glycolytic chain enzymes and antioxidant protection. The mechanisms by which oligosaccharides affect enzymes are still unknown to us.

GOS $1 \%$, FOS $1 \%$ and FOS 5\% are these oligosaccharides, which caused a statistically significant increase of the enzymatic activities of the hexokinase and glutathione reductase in in vitro hyperglycemia induced by $100 \mathrm{mM} \mathrm{Glc}$, as well as an increase in FRAP. Lactate dehydrogenase was decreased in the presence of 5\% lactulose in groups with 50 $\mathrm{mM}$ and $100 \mathrm{mM}$ Glc. These results predetermine further studies on other models of in vitro and in vivo treatment with oligosaccharides and study of their positive effects on the various metabolic pathways in the human body and elucidation of the mechanisms that lead to them.

\section{Abbreviations:}

SCFAs - short chain fatty acids;

GPCR - G-protein coupled receptors;

IL - interleukin;

HDAC - histone deacetylase;

GLP-1 - glucagon like peptide 1;

LPS - lipopolysaccharides;

FOS - fructooligosaccharides;

GOS - galactooligosaccharides;

XOS - xylooligosaccharides;

MOS - manooligosaccharides;

HMO - oligosaccharides from human milk;

DM - diabetes mellitus;

IDF - International Diabetes Federation;

ATP - adenosine triphosphate;

NADPH - reduced nicotinamide adenine dinucleotide phosphate;

HK - hexokinase;

PFK - phosphofructokinase;

PK - pyruvate kinase;

LDH - lactate dehydrogenase;

SOD - superoxide dismutase;

CAT - catalase;

GST - glutathione S-transferase;

GR - glutathione reductase;

GSSG - oxidized glutathione;

GSH - reduced glutathione;

CI - confidence interval

Glc - glucose;

FRAP - ferric reducing antioxidant power

\section{REFERENCES:}

1. Gibson GR, Roberfroid MB. Dietary modulation of the human colonic microflora - introducing the concept of prebiotics. J Nutr. 1995 Jun; 125(6): 1401-12. [PubMed]

2. Hashmi A, Naeem N, Farooq Z, Masood S, Iqbal S, Naseer R. Effect of Prebiotic Galacto-Oligosaccharides on Serum Lipid Profile of Hypercholesterolemics. Probiotics Antimicrob Pro- teins. 2016 Mar;8(1):19-30. [PubMed]

3. Bournet B, Pointreau A, Souque A, Oumouhou N, Muscari F, Lepage B, et al. Gene expression signature of advanced pancreatic ductal adenocarcinoma using low density array on endoscopic ultrasound-guided fine needle aspiration samples. Pancreatology. 2012 Jan-Feb;12(1):27-34. [PubMed]

4. De Vadder F, Kovatcheva-Datchary
P, Goncalves D, Vinera J, Zitoun C, Duchampt A, et al. Microbiota-Generated Metabolites Promote Metabolic Benefits via Gut-Brain Neural Circuits. Cell. 2014 Jan 16;156(1-2): 84-96. [PubMed]

5. Li L, Ma L, Fu P. Gut microbiotaderived short-chain fatty acids and kidney diseases. Drug Des Devel Ther. 2017 Dec 11;11:3531-3542. [PubMed] 
6. Ho J, Reimer RA, Doulla M, Huang C. Effect of prebiotic intake on gut microbiota, intestinal permeability and glycemic control in children with type 1 diabetes: study protocol for a randomized controlled trial. Trials. 2016 Jul 26; 17(1):347. [PubMed]

7. Smith PM, Howitt MR, Panikov N, Michaud M, Gallini CA, BohloolyY M, et al. The microbial metabolites, short-chain fatty acids, regulate colonic Treg cell homeostasis. Science. 2013 Aug 2;341(6145):569-73. [PubMed]

8. Enam F, Mansell TJ. Prebiotics: tools to manipulate the gut microbiome and metabolome. J Ind Microbiol Biotechnol. 2019 Oct;46(9-10):14451459. [PubMed]

9. Davani-Davari D, Negahdaripour M, Karimzadeh I, Seifan M, Mohkam M, Masoumi SJ, et al. Prebiotics: Definition, Types, Sources, Mechanisms, and Clinical Applications. Foods. 2019 Mar 9;8(3):92. [PubMed]

10. Bothe MK, Maathuis AJH, Bellmann S, van der Vossen JMBM, Berressem D, Koehler A, et al. Dose-dependent prebiotic effect of lactulose in a computer-controlled in vitro model of the human large intestine. Nutrients. 2017 Jul 18;9(7):767 [PubMed]

11. Silk DB, Davis A, Vulevic J, Tzortzis G, Gibson GR. Clinical trial: the efects of a trans-galactooligosaccharide prebiotic on faecal microbiota and symptoms in irritable bowel syndrome. Aliment Pharmacol Ther. 2009 Mar 1;29(5):508-18. [PubMed]

12.Hansen $\mathrm{CH}$, Frøkiær H, Christensen AG, Bergström A, Licht TR, Hansen AK, et al. Dietary Xylooligosaccharide Downregulates IFN- $\gamma$ and the Low-Grade Inflammatory Cytokine IL$1 \beta$ Systemically in Mice. J Nutr. 2013 Apr;143(4):533-40. [PubMed]

13. Ferenczi S, Szegi K, Winkler Z, Barna T, Kovács KJ. Oligomannan Prebiotic Attenuates Immunological,
Clinical and Behavioral Symptoms in Mouse Model of Inflammatory Bowel Disease. Scientific Reports. 2016 Sep 23;6:34132. [PubMed]

14. Classification of diabetes mellitus. WHO. 21 April 2019. p.6. [Internet]

15. Viskupicova J, Blaskovic D, Galiniak S, Soszyñski M, Bartosz G, Horakova L, et al. Effect of high glucose concentrations on human erythrocytes in vitro. Redox Biol. 2015 Aug; 5:381-387. [PubMed]

16. Rajab AM, Haider KH. Hyperglycemia and RBCs: too sweet to survive. Int J Diabetes Dev Ctries. 2018 Feb;38:357-365. [Crossref]

17. Harvey WJ, Kaneko JJ. Glucose metabolism of mammalian erythrocytes. J Cell Physiol. 1976 Oct;89(2): 219-24 [PubMed]

18. Mali AV, Bhise SS, Katyare SS, Hegde MV. Altered Kinetics Properties of Erythrocyte Lactate Dehydrogenase in Type II Diabetic Patients and Its Implications for Lactic Acidosis. Indian J Clin Biochem. 2018 Jan;33(1):38 45. [PubMed]

19. Bhise S, Rao J, Hegde M, Katyare S. Type 2 diabetes differentially affects the substrate saturation kinetic attributes of erythrocyte hexokinase and phosphofructokinase. FEBS Letters. 2020 Jan;594(2):240-250. [PubMed]

20. Skrzep-Poloczek B, Poloczek J, Chelmecka E, Dulska A, Romuk E, Idzik M, et al. The Oxidative Stress Markers in the Erythrocytes and Heart Muscle of Obese Rats: Relate to a High-Fat Diet but Not to DJOS Bariatric Surgery. Antioxidants (Basel). $2020 \mathrm{Feb}$ 22;9(2):183. [PubMed]

21. Ferreira ALA, Machado PEA, Matsubara LS. Lipid peroxidation, antioxidant enzymes and glutathione levels in human erythrocytes exposed to colloidal iron hydroxide in vitro. Braz J Med Biol Res. 1999 Jun;32(6):

\section{9-94. [PubMed]}

22. Bergmeyer HU, Bernt E. Lactate dehydrogenase. UV-assay with pyruvate and NADH. In: Methods of Enzymatic Analysis. Bergmeyer HU. (Ed.) Academic Press, New York. 1974 pp.574-578.

23. Bergmeyer HU, Grassl M, Walter HE. In: Methods of Enzymatic Analysis. 3rd ed., vol. 2, Verlag Chemie, Deerfield Beach, FL, 1983:222-223.

24. Mavis RD, Stellwagen E. Purification and Subunit Structure of Glutathione Reductase From Bakers' Yeast. $J$ Biol Chem. 1968 Feb 25;243(4):80914. [PubMed]

25. Benzie IF, Strain JJ. The ferric reducing ability of plasma (FRAP) as a measure of "antioxidant power": The FRAP assay. Anal Biochem. 1996 Jul 15;239(1):70-6. [PubMed]

26. Bradford MM. A rapid and sensitive method for the quantitation of microgram quantities of protein utilizing the principle of protein-dye binding. Anal Biochem. 1976 May 7;72:248254. [PubMed]

27.Pazzini CEF, Colpo AC, Poetini MR, Pires CF, de Camargo VB, Mendez ASL, et al. Effects of Red Wine Tannat on Oxidative Stress Induced by Glucose and Fructose in Erythrocytes in Vitro. Int J Med Sci. 2015 Jun 1;12(6): 478486. [PubMed]

28. González Flecha FL, Bermúdez MC, Cédola NV, Gagliardino JJ, Rossi JP. Decreased Ca2(+)-ATPase activity after glycosylation of erythrocyte membranes in vivo and in vitro. Diabetes. 1990 Jun;39(6):707-11. [PubMed]

29. Resmi H, Akhunlar H, Temiz Artmann A, Güner G. In vitro effects of high glucose concentrations on membrane protein oxidation, G-actin and deformability of human erythrocytes. Cell Biochem Funct. 2005 May-Jun; 23(3):163-8. [PubMed]

Please cite this article as: Dimov I, Choneva M, lliev I, Bivolarska A. Effect of oligosaccharides on enzymes of carbohydrate metabolism and antioxidant protection in in vitro treated erythrocytes under conditions of hyperglycemia. $J$ of IMAB. 2021 Oct-Dec;27(4):4143-4150. DOI: https://doi.org/10.5272/jimab.2021274.4143

Received: 20/01/2021; Published online: 09/12/2021

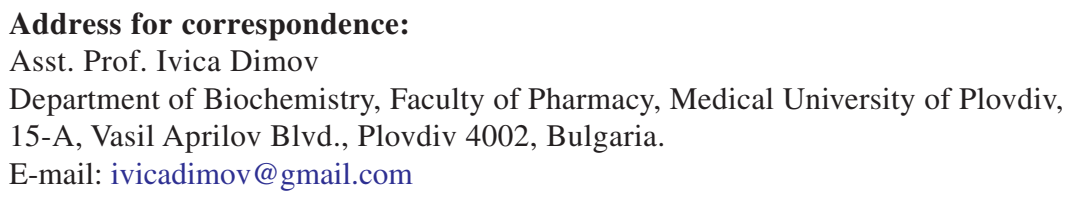

